\title{
С.А. Никольский
}

\section{СОТВОРЕНИЕ ПАМЯТИ. О СТИХАХ ВЛАДИМИРА МАЯКОВСКОГО, ПОЭТА С ШИРОКО ЗАКРЫТЫМИ ГЛАЗАМИ}

Аннотация. Предметом исследования является память в качестве части общественного сознания. В статье её формирование рассматривается на примере творчества Владимира Маяковского - одного из лучших поэтов советской эпохи. Ставятся вопросы: насколько полно в формируемых им поэтических представлениях и образах объективно отражается историческая реальность - общественные явления и события? Ведь в немалой степени по его произведениям позднейшие поколения судят о революции, прочитывают в стихах его оценки происходящего и формируют свои собственные.

Используются методы исторического, философского, эстетического, литературоведческого и культурологического анализа, содержательного сравнения и свободной критической интерпретации.

Основным выводом проведённого исследования является следующий: темы, конкретные сюжеты и создаваемые образы поэта в лучшем случае возникали на основе лозунгов и обещаний, сопровождавших революционный Октябрь. Последующая практика большевистских преобразований была от них не только далека, но иногда и прямо противоположна. Однако поэт предпочитал её либо не видеть, либо - не замечать, прожив жизнь с широко закрытыми глазами.

Ключевые слова: память, литература, поэзия, культура, история, философия культуры, власть, народ, общественное сознание, человек.

Abstract. The subject of this research is the memory as a part of public consciousness. The article examines its formations on the example of the works of one of the most renowned poets of the Soviet era Vladimir Mayakovsky. The author raises the question, how objectively does the poet reflect the historical reality, social phenomena, and events in his poetic ideas? We must acknowledge that the latest generations often base their perception about the revolution on his oeuvres and assessment of the events, and thus form their own. The main conclusion of the conducted research consists in the following: the topics, precise storylines, and created images in Mayakovsky' poetry in best case scenario have emerged based on the slogans and promises, which accompanied the revolutionary October. The further practice of the Bolshevik reformations was far from the, and at times antithetical. However, the poet preferred not noticing it, having lived his life with wide shut.

Key words: Man, Public consciousness, People, Power, Philosophy of culture, History, Culture, Poetry, Literature, Memory.

$\mathrm{H}$ е гаснущий интерес потомков к большим художникам определяется разными основаниями. От Маяковского, чья жизнь совпала со временем революционного слома, мы, кажется, вправе ожидать попытки осмысления революции как процесса, развернувшегося в стране не только в октябре, но и после. Ведь «слово живёт вне себя, в своей живой направленности на предмет... Изучать слово в нём самом, игнорируя его направленность вне себя... бессмысленно» $[2$, с. 105].
При этом важно понимать, что художники - свидетели больших исторических событий - невольные творцы памяти, в которой эти события будут зафиксированы в сознании потомков. И это налагает на них ещё большую меру ответственности.

Попытку осмысления современной ему революционной реальности и, соответственно, конструирования своего варианта памяти, начал предпринимать Александр Блок. То же делали Осип Мандельштам, Андрей Платонов, Варлам Шаламов, Анна Ахматова и ещё многие художники XX века.

Статья подготовлена в рамках проекта РГНФ № 14-03-00192 «Образы прошлого в культуре и общественном сознании россиян ХХ - начала ХХІ века. Социально-билософбский анализ». 
Опыт, память, созданная Маяковским, явила другое. Хотя поэт и жил во время революции, тем не менее, всё же оставался вне многих её существенных проявлений, становившихся, чем далее от Октябрьского переворота, тем более несовместимыми с его лозунгами. Занятое им в жизни и истории место было не в гуще современников, действующих на исторических подмостках, а на авансцене, перед миром-публикой. За редкими исключениями, он не вникает ни в замыслы вершителей революции, ни в их реальные дела. И хотя, по слову Марины Цветаевой, он «первый в мире поэт масс», агитатор, горлан-главарь, но он всё же, вне революции, творец памяти, далёкой от реальности.

Из тех, кто всерьёз пробовал понять Маяковского, прежде всего философ К.М. Кантор в «Тринадцатом апостоле»[12]. Его мысль в том, что история может быть представлена как развивающийся процесс филиации идей, а может - как социокультурная эволюция, которая началась задолго до истории. Потоки идей и реальной жизни - «двойная спираль материально-телесных, душевно-нравственных и духовных движений», которые могут не совпадать. Исходный пункт истории - Иисус Христос. Что до России, то в ней только Маяковский принял всю историю целиком, показал внутреннюю связь учений Христа и Маркса и потому должен именоваться тринадцатым апостолом основателя мировой религии. В СССР уровень социального, промышленного и общекультурного развития столь резко отставал от достигнутого в Западной Европе, что эволюция поглотила историю, которая именно здесь вырвалась на простор. Маяковский, утверждает Кантор, обладал не мудростью знания, а мудростью веры и по этой причине занимался «самой апостольской работой»агитацией и пропагандой нового христианского, почти равного марксовскому, мировоззрения и образа жизни.

И хотя мысли эти кажутся мне искусственными, представим на минуту, что всё было именно так. Но при этом не снимаются вопросы: насколько пропагандируемое учитывало реальную жизнь?

На другую «сторону» Маяковского - собственно творчество поэта, обращает внимание писатель и публицист Д.Л. Быков. Для него «невписываемость» Маяковского в послереволюционную Россию прежде всего результат проявившихся у поэта «титанизма, сверхчеловечности и гиперболизма» - отличительных черт советской эстетики, в то время как послеоктябрьский период чем дальше, тем больше требовал «винтич- ности и будничности». По этой причине футурист-бунтарь стал рупором официоза. По мнению Быкова, парадоксальную актуальность сохраняют не собственно поэтические, а прикладные тексты Маяковского: реклама, окна РОСТА, агитброшюры, политические стихи, выпады против коллег. В них он открыл великое множество риторических приёмов, которые применимы к любой теме и пригодны во всякую эпоху [6]. Значит, снова: поэт Маяковский - не адекватен своему времени, его ведущим идеям и событийному ряду?

«Я не твой, снеговая уродина!», - этой строкой литературовед и писатель Л.А. Аннинский чертит свой знак понимания Маяковского, охватывая его творчество от момента юношеской ненависти как «формулы самоопределения», проклятия тому миру, в котором он появился на свет, до «адовой работы» строительства рая. Но у Аннинского рай Маяковского-агитатора, но не апостола вызывает сомнение: «ради спасения жизни - выкорчевать жизнь. Приобретение в лучшем случае равно утрате. Чтобы всех сделать счастливыми, надо всех скрутить. “Но всех скрутить ужасно трудно”»[1, c. 190]. Опять Маяковский - человек, не адекватный изменяющейся реальности и пытающийся найти способ по собственному разумению изменить жизнь? Способ заведомо гибельный. Или и в самом деле он - «ушагал далеко за нашу современность и где-то за каким-то поворотом долго ещё нас будет ждать» [20, с. 787]?

И, наконец, слово Бориса Пастернака: «Его место в революции, внешне столь логичное, внутренне столь принуждённое и пустое, навсегда останется для меня загадкой» [5, с. 275]. Принуждение - внешнее (других) или собственное (самого себя)? В итоге - место пустое.

Место поэта вне революции неожиданным образом аукнулось недавно, в 2007-м, в год столетнего юбилея Варлама Шаламова, когда вышел телефильм «Завещание Ленина». В ленте, поставленной по произведениям Шаламова (сценарист Юрий Арабов и режиссёр Николай Досталь), есть придуманная кинематографистами сцена. Один из заключённых по заданию администрации лагеря выдаёт себя за Хренова - героя стиха Маяковского и читает в бараке «Рассказ Хренова о Кузнецкстрое и людях Кузнецка». Рефрен стиха:

«Через четыре

года

здесь

будет

город-сад!» 


\section{Философия и культура 9(105) • 2016}

выливается в финальное - гордое обещаниеуверенность:

«Я знаю -

город

будет,

я знаю -

саду

цвесть,

когда

такие люди

в стране

советской

есть!» [16, с. 698-699].

Эпизод завершается истошным криком персонажа: «Б...! Я жрать хочу, не могу! Жрать хочу! Дайте...».

Пафосный стих-агитку поэта интерпретаторы столкнули с реальностью. У Маяковского строители всего лишь в дождь сидят под телегою и жуют подмокший хлеб. Но их трудное житьё не сравнимо с зэковским существованием на грани смерти. Ведь уже к 1929 г. зэки стали большим советским миром: только за «контрреволюционные преступления» в СССР было осуждено около 600 тысяч. В этом же году принято решение о создании сети лагерей для «эксплуатации их природных богатств» и зимой 1930 в них поместили 400 тысяч заключённых $[11$, с. 820]. 0 чём же слово Маяковского? Отражает оно мнимый или подлинный предмет?

Вологодский исследователь творчества Шаламова В. Есипов вступил в полемику с авторами фильма по поводу персонажа Хренова. Он полагает, что вольность создателей фильма в отношении Хренова не уместна ни в контексте стиха Маяковского, ни прозы писателя. Но исследователь не только бесстрастный учёный. Он считает, что тенденция очернить образ Ленина - не только отечественный продукт «либеральных общественных настроений», но и результат усилий западных недоброжелателей, желающих «создать негативный образ России как страны “невыученных уроков"» [10]. По его мнению, во время начала строительства завода, рабочие были исключительно свободными людьми, а «контрреволюционеры», крестьяне и прочие ставшие зэками репрессированные, строили Кузнецк позднее.

Оставим спор в стороне. Упоминание о нём потребовалось, чтобы показать важность рассуждения о предмете поэзии, органично связанной со своим временем, и заострить вопрос: насколько Маяковский как современник революции был адекватен изменяющейся реальности, включён в процессы, протекавшие в стране через годы после переворота 25 октября? В том числе, если признать (что я и делаю), что революция не завершилась собственно октябрьским переворотом, а продолжалась по крайней мере до завершения коллективизации и политических расстрельных процессов тридцатых годов.

Выполнять эту работу далее я буду посредством сопоставления - вынужденно схематичного и выборочного параллельного рассмотрения исторического событийного ряда и анализа идей и тематического содержания некоторых знаковых произведений поэта тех же лет. При этом за рамками статьи останутся многие бесспорные (вневременные) шедевры поэтического творчества Владимира Маяковского.

С весны 1918 г. большевики начали проводить политику военного коммунизма. Среди её составных частей главными была продразвёрстка, уничтожение кооперации, введение всеобщей трудовой повинности, «культурная революция», гонения на религию и разграбление церкви. Одним из следствий этой политики, наряду с природным фактором, стал голод 1921-1922 гг. [18].

Для понимания существа продразвёрстки принципиальное значение имеют выводы В.И. Ленина конца 1921 г. «Переход к "коммунизму" очень часто (и по военным соображениям; и по почти абсолютной нищете; и по ошибке, по ряду ошибок) был сделан без промежуточных ступеней социализма» [14, с. 473]. В 1918-1920 гг. «...мы сделали ту ошибку, что решили произвести непосредственный переход к коммунистическому производству и распределению. Мы решили, что крестьяне по развёрстке дадут нужное нам количество хлеба, а мы разверстаем его по заводам и фабрикам, - и выйдет у нас коммунистическое производство и распределение» [14, с. 157]. В итоге «...мы к весне 1921 г. потерпели поражение... Развёрстка в деревне, этот непосредственный коммунистический подход к задачам строительства в городе, мешала подъёму производительных сил и оказалась основной причиной глубокого экономического и политического кризиса, на который мы наткнулись весной 1921 года» [14, с. 159].

Летом 1918 г. в деревнях начали действовать комитеты деревенской бедноты, созданные вместо упразднённых советов, большевикам не подчинявшихся. «Это комитеты в течение нескольких месяцев провели в деревне на деле в жизнь перераспределение пользования землей, забирали от имеющих несколько лошадей крестьян избыточное против минимальной потребности количество и передавали его начинающим собственное хозяй- 
ство беспосевным и малосеющим и т.п. ...одновременно помогая также городским рабочим принудительно извлекать излишки хлеба от прежнего крупного крестьянства («кулаки»). Конституционные сельские и волостные «советы» были отодвинуты на задний план в период (свыше полугодия) деятельности «комитетов бедноты», фактически проводивших аграрную революцию в деревне. Их деятельность вызвала длительный ряд вооружённых восстаний известной части крестьян почти по всем уездам Советской России...» [13, с. 14]. Политика продразвёрстки быстро обрела популярность, а динамика заготовок была такова:

«1917/18 г. - 73,4 млн. пуд. = 100\%

1918/19 г. $-107.9=147,0 \%$ (в сравнении с исходной величиной)

$1919 / 20$ г. $-212.5=289,5 \%$

$1920 / 21$ г. $-367,0=500 \% »[21$, с. 19$]$.

Что знал об аграрной политике большевиков певец революции? В какой-то мере об уровне его осведомлённости свидетельствует стихотворение 1920 г. «Всем Титам и Власам РСФСР»? Герои - два брата-кулака, которым для ремонта дома потребовались гвозди. Старший Тит - «глупый, как камень», отправляется в город и обнаруживает неработающий гвоздильный завод, в котором:

«Рабочий зря без дел сидит.

«Я, - говорит, - голодный.

Дай, Тит, рабочим хлеб взаймы,

Мы здесь сидим не жравши,

А долг вернём гвоздями мы

Крестьянам, хлеба давшим».

Взъярился Тит: «Не дам, не дам

Я хлеба дармоеду.

Не дам я хлеба городам,

И без гвоздя доеду» [16, с. 72].

Дело поправляет другой брат:

«Влас молвил, Тита поумней.

«Ну что ж, бери, родимый,

Наделаешь гвоздей и мне

Ужо заплатишь ими».

Рабочий сыт, во весь свой пыл

В трубу дымище гонит.

Плуги, и гвозди, и серпы

Деревне мчит в вагоне.

Ясней сей песни нет, ей-ей, Кривые бросим толки.

Везите, братцы, хлеб скорей,

Чтоб вас не съели волки» [16, с. 73]
На разразившийся в стране в 1921-1922 гг. голод, в немалой степени рукотворный, Маяковский откликнулся стихами «Когда голод грыз прошлое лето, что делала власть советов?»

«Все знают:

в страшный год,

когда

народ (и скот оголодавший) дох,

и ВЦИК

и Совнарком

скликали города,

помочь старались из последних крох.

Когда жевали дети глины ком,

когда навоз и куст пошли на пищу люду,

крестьяне знают -

каждый исполком

давал крестьянам хлеб,

полям давал семссуду.

Когда ж совсем невмоготу пришлось Поволжью -

советским ВЦИКом был декрет по храмам дан:

- Чтоб возвратили золото чинуши божьи,

на храм помещиками собранное с крестьян. -

ныне:

Волга ест,

в полях пасется скот.

Так власть,

в гербе которой «серп и молот»,

боролась за крестьянство в самый тяжкий год и победила голод» [16, с. 129].

Для полноты рассмотрения вопроса о включённости поэта в реальную жизнь страны приведу сделанное десятью годами позже наблюдение Осипа Мандельштама, не менее чем Маяковский, далёкого от аграрной проблематики:

«Природа своего не узнает лица,

И тени страшные Украйны и Кубани...

На войлочной земле голодные крестьяне

Калитку стерегут, не трогая кольца» [15].

Причинами голода 1921-1922 гг., как известно, была не только засуха в производящих хлеб регионах, политика продразвёрстки, в ответ на которую крестьяне, экономя зерно, сокращали посевы, не только ставшее следствием запустения полей «мышиное бедствие», но и большевистское планирование, для чего создавался гигантский управленческий аппарат. В частности, был образован Народный комиссариат продовольствия. Уничтожив свободную торговлю и кооперацию как своего главного конкурента (в широком хождении была мысль «У кого хлеб, у того и власть»), большевики 
сделали ставку на бюрократический аппарат. Его численность постоянно росла. К примеру, штаты одного только центрального аппарата менялись так: на 1 января 1919 г. - 1703 человек, на 1 января 1920 г. - 2500, на 1 января 1921 г. - 6846 и, наконец, к осени 1921 г. - 7667 человек. Весь же личный состав Наркомпрода РСФСР на 1921 г. составил 144913 человек (в том числе 13874 ответственных сотрудников) [7, с. 61].

Наркомпрод организовывал продовольственное снабжение 35 миллионов потребителей. Кто же входил в их число, не считая армию, численность которой в годы гражданской войны колебалась от 4 до 6 миллионов человек? «1. Рабочие фабр.-заводов, промышлен, (с семьями)... 6461 тысяча человек. 2. Рабочие транспорта (с семьями) ... - 476759. 3. Общественное питание, детское питание и другие группы городских потребителей 21861 тысяча. 4. Кустари - 2020» [7, с. 61].

Бросается в глаза, заключает автор, не только громадное количество едоков, но и сравнительно незначительное количество рабочих транспорта и промышленности с семьями (11 млн. чел.). Сколько бюрократии обеспечивалось согласно «резиновой» статьи «общественное питание» и замаскировано пунктом «общественное и детское питание и другие группы городских потребителей»?

На рост бюрократии В. Маяковский, как известно, откликнулся стихотворением «Прозаседавшиеся» (1922 г.), получившим похвалу Ленина и ставшим хрестоматийным. В частности, выходило - и это откладывалось в памяти для будущих поколений, что власти не ущербно организуют и управляют, безмерно потребляют, но всего лишь много заседают.

Можем ли мы формулировать суждение по поводу того, на что поэт не обратил внимания? Подозревать его, например, в нежелании взглянуть на проблему глубже? Думаю, вообще такого рода замечания не верны. Однако в случае, когда поэт, приписавший себе право говорить от «имени масс», не раз и не два обходит стороной (не замечает или делает вид, что не замечает) проблемы, которые для масс являются жизненно важными, право на оценку у читателя возникает.

Кроме трагических событий продразверстки и голода, Владимир Маяковский также счёл нужным включиться в развёрнутую большевиками борьбу против православия, использовав для этого повод конфискации советской властью церковных ценностей. Следует отметить, что ещё в начале 1922 г. Церковь добровольна начала жертвовать в помощь голодающим ценные предметы, не имеющие богослужебного употребления. Признание этого факта, однако, не входило в планы антирелигиозной борьбы властей, и с марта началась их принудительная конфискация. При том, что конфискованное имущество оценивалось в 25 миллиардов злотых рублей, на помощь голодающим было истрачено лишь около 1 миллиона: в тогдашних первоочередных заботах власти было разжигание мирового революционного пожара. Сопротивление верующих ограблению жестоко подавлялось. Так, только в результате развязанного ГПУ террора, в 1922-1923 гг. было убито 2690 священников, 5410 монахов и монахинь, закрыто 637 монастырей [11, с. 809].

Вряд ли эти события могли остаться не известными людям, живо интересовавшимся политикой, не затронули гуманитарные и интеллигентские круги, в которых вращался пролетарский поэт. Однако откликнулся он на них торжествующе-злым стихом «Когда мы побеждали голодное лихо, что делал патриарх Тихон?»:

«Тихон патриарх, прикрывши пузо рясой, звонил в колокола по сытым городам, ростовщиком над золотыми трясся:

«Пускай, мол, мрут,

а злата -

не отдам!»

Чесала языком их патриаршья милость, и под его христолюбивый звон

на Волге дох народ,

и кровь рекою лилась -

из помутившихся

на паперть и амвон.

Осиротевшие в голодных битвах ярых!

Родных погибших вспоминая лица,

знайте:

Тихон

патриарх

благословлял убийцу.

За это

власть Советов,

вами избранные люди, -

господина Тихона судят» $[16$, с. 130$]$.

Приведённые примеры «встречи» поэта с реальностью, его методы сотворения памяти ставят вопросы, на которые нужно давать ответ. Кто способствовал голоду - рукотворному и стихийному бедствию? Кто организовал травлю священников и верующих? Получаемые ответы будут отличны от ответов Владимира Маяковского. И дело не только в исторической дистанции, дающей известную фору в понимании происходящего. Факту выборочного видения или слепоты в отношении того, 
что видели в России все, кто имел глаза, требуется объяснение. Похоже, здесь уместны слова Марины Цветаевой: «сколько ни заявляй Маяковский: “Я - это всё! Я - это мы!” - он всё-таки одинокий товарищ, неравный ровня, атаман - ватаги, которой нет, или настоящий атаман которой - другой» (выделено мной - C.H.) [20, с. 795].

Борьба новой власти против старой культуры в послеоктябрьские годы также была в числе её политических приоритетов. И если по другим направлениям личные мотивы Маяковского и устремления власти не пересекались и поэт вправе был выбирать, на что откликаться, то в области культуры мотивации власти и поэта совпали. Большевики ставили задачу тотального пересмотра содержания прошлой культуры, приспособления отдельных её ценностей к своим целям, а в случае невозможности решения этой задачи - их радикального переосмысления или отбрасывания. Среди практически полностью отвергнутых были Ф.М. Достоевский и Н.С. Лесков. В числе коренным образом переосмысленных - А.С. Пушкин. В частности, в соответствии с задачей создания советского варианта ценностей отечественной культуры был написан сценарий фильма по повести А.С. Пушкина «Капитанская дочка», получившей в советском кинематографе название «Гвардии сержант». Об этом фильме в аннотированном каталоге «Советские художественные фильмы» было сказано, что сценарист и режиссёр избрали путь «исправления» исторических ошибок, присущих пушкинскому произведению. Сохранив фабульную канву повести, экранизаторы «заново переписывают» образы основных героев, а «сценарист и режиссер модернизируют историческую концепцию произведения в духе школы Покровского» [19, с. 267-268]. Как писал в то время В. Шкловский, «Капитанская дочка» для того и была написана Пушкиным не от своего имени, а под маской простодушного и неумного Гринева, чтобы сгладить социальные противоречия, лежащие в основе пугачевщины. Повесть была сделана Пушкиным так, чтобы «не дать (не показать - C.H.) крепостное право», не дать заинтересованность дворян в наступлении на степь; ослаблены силы Екатерины в степи и вместо крепости дан какой-то загончик, в котором живут милые люди, обижаемые разбойниками. ...Пушкин уже для своего времени лжёт в своём произведении» [8, с. 104].

Отношение Маяковского к великим предшественникам также нельзя назвать почтительным, уважительным или бережным. Хотя в этом случае поэт озабочен сотворением памяти не о событиях, а о себе. Возможно, в данном случае прав М.М. Бахтин, отмечавший: «До конца творчества монумен- тализм у М. оставался фамильярным» [3, с. 52]. Но где граница между фамильярностью и хамством? В стихах «Тамара и Демон» (1924 г.) автор, например, обращаясь к Тамаре, пошло, но непринуждённо роняет:

«Я знаю вас

мне

много про вас

говаривал

некий Лермонтов.

Он клялся,

что страстью

и равных нет...

Таким мне

мерещится образ твой.

Любви я заждался,

мне 30 лет.

Полюбим друг друга.

Попросту.

Да так,

чтоб скала

распостелилась в пух.

От черта скраду

и от бога я!

Ну что тебе Демон?

Фантазия!

Дух!

К тому ж староват -

мифология.

...

К нам Лермонтов сходит,

презрев времена.

Сияет -

«Счастливая парочка!»

Люблю я гостей.

Бутылку вина!

Налей гусару, Тамарочка!» [16, с. 247-248].

Похоже, это тот случай, когда отсутствие стихов принесло бы поэту больше уважения потомков, чем их наличие.

В обращении Маяковского Пушкин заслуживает несколько большего уважения. Не исключаю, что при всей своей демонстративной независимости и смелости весьма чуткий к движениям власти пролетарский поэт уловил её предпочтения в отношении тех, кого она желала записать в когорту своих культурных предшественников. Ведь и в поэму «Владимир Ильич Ленин», датированную 1924 г., поэт включает строки:

«Штыками

тычется

чирканье молний,

матросы 


\section{Философия и культура 9(105) • 2016}

в бомбы

играют, как в мячики.

От гула

дрожит

взбудораженный Смольный.

В патронных лентах

внизу пулемётчики.

- Bac

вызывает

товарищ Сталин.

Направо

третья,

oH

там» $[16$, с. 944].

Маяковский в Смольном в дни Октябрьского переворота был. Сталин не был. Зачем понадобился домысел?

Что же до Пушкина, то в прошлом футуристбунтарь, носившийся с Манифестом - «Только мы - лицо нашего Времени. ....Бросить Пушкина, Достоевского, Толстого и проч. и проч. с Парохода современности» $[17$, с. 83], теперь радикально переориентировался. Официально автор «Евгения Онегина» признан властями национальным достоянием, его 125-летие со дня рождения помпезно отмечается и Маяковский пишет «Юбилейное»:

«не

при жизни

с вами

сговориться б надо.

Скоро вот

и я

умру

и буду нем.

После смерти

нам

стоять почти что рядом:

вы на Пе,

а я

на эМ» $[16$, с. 235$]$.

Общеизвестно, что «злоба дня» довлеет в творчестве Маяковского. Но проявляется она всего лишь по нескольким тематическим линиям. Это, конечно, революционный энтузиазм, передовые позиции СССР в окружающем мире капитала.

Постепенно, к концу жизни поэта, сюжеты концентрируются вокруг узкого круга повторяющихся «злободневных» тем и, наконец, в своём повторении-соединении всплывают в «Клопе» и «Бане». Исчезла их «актуальность» - лобовое («апостольское», агитационно-плакатное) бичевание мещанства и превознесение светлого будущего. Так, в
«Клопе» бывший рабочий и бывший партиец Присыпкин (Скрипкин) разоблачается поэтом в качестве «перерожденца»: «...За што я боролся? Я за хорошую жизнь боролся. Вон она у меня под руками: и жена, и дом, и настоящее обхождение» [16, с. 1214]. В будущем, через пятьдесят лет, место Присыпкина поэт определяет в зоологическом саду вместе с натуральным клопом - другим экспонатом 20-х гг. И оба являются «теплящиеся слабым напоминанием прошлого, подчеркивают ужас поверженного времени и мощь и трудность культурной борьбы рабочего человечества» [16, с. 1233].

Сюжет «Бани» мало отличается от сюжета «Клопа». Главный герой тоже бюрократ, которого не берут в светлое будущее. В «драме» похождения изобретателя машины времени приводят к появлению в СССР 1930 г. «фосфорической женщины» из года 2030. У посланницы есть «мандат» на «отбор» и «переброску лучших в коммунистический век». При этом оказывается, что «учёные из будущего» с самого начала наблюдали за опытом Октября, «учитывая и корректируя ...неизбежные просчёты. Мы шли друг к другу, как две бригады, прорывающие тоннель, пока не встретились сегодня» [16, с. 1261]. Политический ход, своего рода полученная из будущего лицензия-сертификат, подтверждающая правильность содеянного?

По мере общения «фосфорической женщины» с героем драмы Победоносиковым - бездельником и бюрократом с четвертьвековым стажем, обнаруживается, что он не соответствует главному критерию отбора. А это, по словам «фосфорической женщины» - «радость работать, жажда жертвовать, неутомимость изобретать, выгода отдавать гордость человечностью». Поэт верит, что «летящее время сметёт и срежет балласт, отягчённый хламом, балласт опустошенных неверием» [16, c. 1271]. Время в виде неумолимой машины оставляет Победоносикова и ряд подобных ему персонажей в прошлом. Звучит «марш времён».

$$
* * *
$$

Идеи, идеалы и лозунги календарного 25 октября 1917 г., воспринятые Маяковским именно во время петроградских событий, неуклонно тиражировались-переиздавались вплоть до кончины в апреле 1930 г. К тому же, не исключено, что поэт и в самом деле верил, что его Слово - высшая сила, способная творить реальность.

Предложенный критический ракурс рассмотрения революционного творчества Владимира Маяковского, само собой, не является попыткой по- 
влиять на его оценку как большого поэта. Есть множество стихов, которыми поэт и в самом деле «раздвигает пространство» и это «явно до всякой своей роли “исторического свидетельства" имеет гораздо более близкий ...смысл выхода из тесноты на простор, события, которое на более привычном языке называется вдохновением, которое лучше понимать самым широким образом, почти формально как расширение при вдыхании воздуха» [4, с. 22]:

\section{«...Снег заносит}

косые кровельки,

серебрит телеграфную сеть, он схватился

за холод проволоки

и остался

на ней

висеть» $[16$, с. 516].

Тем не менее, Октябрь навсегда остался-застыл в глазах Маяковского, а на последующее время он смотрел широко закрытыми глазами. А, может, накануне рокового дня жизнь открылась ему именно такой, какой она в реальности и была?

\section{Список литературы:}

1. Аннинский Лев. Красный век. Эпоха и её поэты. Т. 1. М.: ПРОЗАиК, 2009. 429 с.

2. Бахтин М.М. Вопросы литературы и эстетики. Исследования разных лет. М.: Художественная литература, 1975.504 с.

3. Бахтин М.М. Собр. соч. Т. 5. М.: Русские словари, 1997. 731 с.

4. Бибихин В.В. Грамматика поэзии. Новое русское слово. СПб.: Изд-во Ивана Лимбаха, 2009. 590 с.

5. Быков Дмитрий. Борис Пастернак. ЖЗЛ. М.: Молодая гвардия, 2006. 893 с.

6. Быков Дмитрий. Тринадцатый апостол. Маяковский. Трагедия-буфф в шести действиях. М.: Молодая гвардия, 2016. 827 с.

7. Вышинский А. Цели и задачи государственного плана снабжения // Четыре года продовольственной работы. М., 1922. С. 60-61.

8. Гуральник У.А. Русская литература и советское кино. Экранизация классической прозы как литературоведческая проблема. М.: Наука, 1968. 431 с.

9. Давыдов М.И. Борьба за хлеб. М.: Мысль, 1971. 219 с.

10. Есипов Валерий. Что завещал Ленин и что - Шаламов? URL: http://shalamov.ru/ru/critique/152/.

11. История России. ХХ век. Т. 1. 1894-1939. М.: Астрель: АСТ, 2009. 1023 с.

12. Кантор К.М. Тринадцатый апостол. М.: Прогресс-Традиция, 2008. 368 с.

13. Ларин Ю., Крицман Л. Очерк хозяйственной жизни и организация народного хозяйства Советской России. М., 1920. C. 14-15.

14. Ленин В.И. Полн. собр. соч. М.: Изд-во политической литературы, 1970. Т. 44. С. 157-159; 472-473.

15. Мандельштам Осип. Полное собрание поэзии и прозы в одном томе. М.: АЛЬФА-КНИГА, 2010. 1182 с.

16. Маяковский Владимир. Полн. собр. стихотворений, поэм и пьес в одном томе. М.: Альфа-книга, 2011. 1327 с.

17. Михайлов Ал. Маяковский. ЖЗЛ. М.: Молодая гвардия, 1988. 558 с.

18. Никольский С.А Аграрный курс России. Мировоззрение реформаторов и практика аграрных реформ в социальноисторическом, экономическом и философском контекстах. М.: КолосС, 2003. 375 с.

19. Советские художественные фильмы. Аннотированный каталог. Т. 1. М.: Искусство, 1961. 527 с.

20. Ц Цветаева Марина. Полн. собр. поэзии, прозы, драматургии в одном томе. М.: АЛЬФА-КНИГА, 2010. 1314 с.

21. Челяпов И. Почему партия проводила политику военного коммунизма. М.: Госполитиздат, 1959. С. 18-20.

22. Антонова E.M. Ad Libitum: Философия и поэзия. // Филология: научные исследования. 2011. № 2. С. 24-29.

23. Репина Л.П. Память о прошлом как яблоко раздора, или Ещё раз о (меж)дисциплинарности // Исторический журнал: научные исследования. 2013. № 1. C. 25-32. DOI: 10.7256/2222-1972.2013.01.3.

\section{References (transliterated):}

1. Anninskii Lev. Krasnyi vek. Epokha i ee poety. T. 1. M.: PROZAiK, 2009. 429 s.

2. Bakhtin M.M. Voprosy literatury i estetiki. Issledovaniya raznykh let. M.: Khudozhestvennaya literatura, $1975.504 \mathrm{s.}$

3. Bakhtin M.M. Sobr. soch. T. 5. M.: Russkie slovari, 1997. 731 s.

4. Bibikhin V.V. Grammatika poezii. Novoe russkoe slovo. SPb.: Izd-vo Ivana Limbakha, 2009. $590 \mathrm{~s}$.

5. Bykov Dmitrii. Boris Pasternak. ZhZL. M.: Molodaya gvardiya, 2006. $893 \mathrm{~s}$.

6. Bykov Dmitrii. Trinadtsatyi apostol. Mayakovskii. Tragediya-buff v shesti deistviyakh. M.: Molodaya gvardiya, $2016.827 \mathrm{~s}$.

7. Vyshinskii A. Tseli i zadachi gosudarstvennogo plana snabzheniya // Chetyre goda prodovol'stvennoi raboty. M., 1922. S. 60-61.

8. Gural'nik U.A. Russkaya literatura i sovetskoe kino. Ekranizatsiya klassicheskoi prozy kak literaturovedcheskaya problema. M.: Nauka, 1968. 431 s.

9. Davydov M.I. Bor'ba za khleb. M.: Mysl', 1971. 219 s.

10. Esipov Valerii. Chto zaveshchal Lenin i chto - Shalamov? URL: http://shalamov.ru/ru/critique/152/.

11. Istoriya Rossii. XX vek. T. 1. 1894-1939. M.: Astrel': AST, 2009. 1023 s.

12. Kantor K.M. Trinadtsatyi apostol. M.: Progress-Traditsiya, 2008. 368 s. 


\section{Философия и культура 9(105) • 2016}

13. Larin Yu., Kritsman L. Ocherk khozyaistvennoi zhizni i organizatsiya narodnogo khozyaistva Sovetskoi Rossii. M., 1920. S. 14-15.

14. Lenin V.I. Poln. sobr. soch. M.: Izd-vo politicheskoi literatury, 1970. T. 44. S. 157-159; 472-473.

15. Mandel'shtam Osip. Poln. sobr. poezii i prozy v odnom tome. M.: AL'FA-KNIGA, 2010. $1182 \mathrm{s.}$

16. Mayakovskii Vladimir. Poln. sobr. stikhotvorenii, poem i p'es v odnom tome. M.: Al'fa-kniga, $2011.1327 \mathrm{s.}$

17. Mikhailov Al. Mayakovskii. ZhZL. M.: Molodaya gvardiya, 1988. $558 \mathrm{~s}$.

18. Nikol'skii S.A. Agrarnyi kurs Rossii. Mirovozzrenie reformatorov i praktika agrarnykh reform v sotsial'no-istoricheskom, ekonomicheskom i filosofskom kontekstakh. M.: KolosS, 2003. 375 s.

19. Sovetskie khudozhestvennye fil'my. Annotirovannyi katalog. T. 1. M.: Iskusstvo, $1961.527 \mathrm{~s}$.

20. Tsvetaeva Marina. Poln. sobr. poezii, prozy, dramaturgii v odnom tome. M.: AL"FA-KNIGA, 2010.1314 s.

21. Chelyapov I. Pochemu partiya provodila politiku voennogo kommunizma. M.: Gospolitizdat, 1959. S. 18-20.

22. Antonova E.M. Ad Libitum: Filosofiya i poeziya. // Filologiya: nauchnye issledovaniya. 2011. № 2. S. 24-29.

23. Repina L.P. Pamyat' o proshlom kak yabloko razdora, ili Eshche raz o (mezh)distsiplinarnosti // Istoricheskii zhurnal: nauchnye issledovaniya. 2013. № 1. S. 25-32. DOI: 10.7256/2222-1972.2013.01.3. 